\section{References}

1 Silverman M, Connolly N M, Balfour-Lynn L, Godfrey S. Long-term trial of disodium cromoglycate and isoprenaline in children with asthma. $\mathrm{Br}$ Med J 1972; iii: 378-81.

2 Weinberger M M, Bronsky E A. Evaluation of oral bronchodilator therapy in asthmatic children. $J$ Pediatr $1974 ; 84: 421-7$.

3 Godfrey S, Balfour-Lynn L, König P. The place of Cromolyn Sodium in the long-term management of childhood asthma based on a 3- to 5-year follow-up. $J$ Pediatr 1975; 87: 465-73.

4 Hambleton F. Weinberger M, Taylor J, et al. Comparison - of cromoglycate (Cromolyn) and theophylline in controlling symptoms of chronic asthma. Lancet 1977; i: 381-5.

5 Hiller E J, Milner A D, Lenney W. Nebulised sodium cromoglycate in young asthmatic children. Arch Dis Child $1977 ; 52$ : 875-6.

6 Tanner J M, Whitehouse R H, Takaishi M. Standards from birth to maturity for height, weight, height velocity, and weight velocity: British children, 1965. Arch Dis Child $1965 ; 41$ : 454-71; 613-35.

- Mantel N. Chi-square tests with one degree of freedom: extensions of the Mantel-Haenszel procedure. $\mathrm{Am}$ Statistical Assoc J 1963; 58: 690-700.

8 Godfrey S. The relative merits of Cromolyn Sodium and high-dose theophylline therapy in childhood asthma. $J$ Allergy Clin Immunol 1980; 65: 97-104.

Correspondence to Professor H Simpson, Department of Child Health, University of Leicester, University Road, Leicester LE1 7RH.

Received 12 March 1981

\title{
Testicular complications in connective tissue disease
}

\author{
N J TANGNEY
}

Department of Paediatrics, Bon Secours Hospital, Cork, Ireland

SUMMARY Acute testicular symptoms are described in 2 patients with Schönlein-Henoch syndrome and in 1 with juvenile rheumatoid arthritis. The literature on testicular involvement in connective tissue disease of childhood is reviewed.

Testicular vasculitis in Schönlein-Henoch syndrome is mentioned in only one current general paediatric textbook. ${ }^{1}$ None the less, the phenomenon is well known, and Sahn and Schwartz ${ }^{2}$ reported the finding in 5 of a series of 20 patients, 13 of whom were boys. Two more cases are here described, together with what is, as far as I can establish, the first recorded case of testicular involvement in juvenile rheumatoid arthritis.

\section{Patients}

Case 1. A 7-year-old boy was admitted with acute left scrotal pain and swelling. He had had an upper respiratory tract infection during the previous week but there were no other symptoms. Exploration showed the testis and epididymis to be swollen and congested but there was no torsion. Postoperatively, he developed swelling of his right wrist and an extensive urticarial rash on the backs of his legs, thighs, and buttocks. Schönlein-Henoch syndrome was diagnosed.

\section{Investigative findings}

Erythrocyte sedimentation rate (ESR) was $52 \mathrm{~mm} / 1 \mathrm{st}$ hour. Urine analysis showed a trace of albumin and a few red cells. The following investigations were normal or negative: full blood count, stool examination for occult blood, antistreptolysin $O$ titre (O-AST), tests for LE cells, antinuclear and antiDNA antibodies, and rheumatoid factor. He was treated with paracetamol and made a good recovery within a week.

Case 2. A $7 \frac{1}{2}$-year-old boy was referred with a 3-week history of abdominal cramps, vomiting, diarrhoea, and a rash. He had developed painful swelling of both ankles 48 hours before admission. On examination he had an extensive haemorrhagicurticarial rash over his lower limbs, including the buttocks, and on the forearms. Both feet were oedematous and there was painful swelling of both ankle joints.

\section{Investigative findings}

Urine analysis showed large numbers of red cells and some cellular casts. Stools were strongly positive for occult blood. The following investigations were normal or negative: full blood count, ESR, clotting studies, O-AST, serum complement, tests for LE cells, antinuclear antibodies, rheumatoid factor, blood urea, creatinine, and electrolyte levels.

Schönlein-Henoch syndrome was diagnosed and, because of the severity and duration of his abdominal pain, he was started on prednisolone $10 \mathrm{mg}$, three times a day. His condition improved on this regimen but, on the 7th day in hospital, he developed acute 
left scrotal pain and swelling. Exploration showed an infarcted epididymis and a blue, congested testis without torsion. He gradually recovered and has remained well.

Case 3. An $8 \frac{1}{2}$-year-old boy, with an established diagnosis of polyarticular-type juvenile rheumatoid arthritis, was admitted with a 24-hour history of acute, painful swelling of his right testis. The rheumatoid disease had been well controlled with aspirin for more than a year but this had been stopped by his dentist 2 weeks before admission because some dental extractions were planned. $\mathrm{He}$ had begun to suffer malaise, joint pains, and lowgrade fever 10 days before admission.

On examination, he was ill-looking with a temperature of $39 \cdot 2^{\circ} \mathrm{C}$. His right scrotum was swollen and tender, and he had painful swelling of numerous small joints of his hands and feet. He had generalised lymphadenopathy and splenomegaly.

\section{Investigative findings}

ESR was $92 \mathrm{~mm} / 1 \mathrm{st}$ hour. Latex agglutination test was positive. The following investigations were normal or negative: full blood count, blood culture, urine analysis, and tests for LE cells, antinuclear, and anti-DNA antibodies.

Exploration of the scrotum showed a swollen, congested testis but there was no torsion. Postoperatively, aspirin was restarted, the symptoms gradually subsided, and the ESR returned to normal.

\section{Discussion}

Polyarteritis nodosa is a known cause of testicular symptoms in children and can be diagnosed by testicular biopsy. ${ }^{1}$ A connection between it and Schönlein-Henoch syndrome has been suggested ${ }^{3}$ and the latter is the only other connective tissue disease of childhood in which testicular involvement has often been reported. A link has also been suggested, on both clinical and pathological grounds, between polyarteritis nodosa and mucocutaneous lymph node syndrome ${ }^{4}$ and testicular involvement has been reported in the latter condition. ${ }^{5}$
Vasculitis is rare in juvenile rheumatoid arthritis and occurs only in patients who possess rheumatoid factor. ${ }^{6}$ Case 3, who was rheumatoid factor-positive, did not have extratesticular vasculitic features but his testicular symptoms were part of a general flare-up of rheumatoid disease and a vasculitic mechanism seems likely. Testicular involvement is fairly common in Schönlein-Henoch syndrome and polyarteritis nodosa, and may be more common in other connective tissue disorders than is generally recognised. The possibility of connective tissue disease should be considered in the assessment of any child with acute testicular symptoms. If doubt exists as to the need for surgical exploration, radioisotope imaging of the scrotum can help to distinguish torsion from other causes of painful testicular swelling. ${ }^{7}$

I thank Dr S O'Donoghue for allowing me to report Case 2.

\section{References}

1 Schaller J G, Wedgwood R J. Rheumatic diseases of childhood. In: Vaughan V C, McKay R J, Behrman R E, eds. Nelson textbook of pediatrics, eleventh edition. Philadelphia: Saunders, 1979: 651-82.

2 Sahn D J, Schwartz A D. Schönlein-Henoch syndrome: observations on some atypical presentations. Pediatrics $1972 ; 49: 614-6$.

3 Meadow R. Schönlein-Henoch syndrome. Arch Dis Child 1979 ; 54: 822-4.

4 Lightfoot $\mathrm{R}$ W. Infantile polyarteritis nodosa. In: McCarty D J, ed. Arthritis and allied conditions, ninth edition. Philadelphia: Lea \& Febiger, 1979: 731-2.

5 Connolly K D, Timmons D. Mucocutaneous lymph node syndrome with testicular involvement. Ir J Med Sci 1980; 149: $26-7$.

6 Bywaters E G L. Vasculitis and the rheumatoid nodule. In: Duthie J J R, Alexander W R M, eds. Rheumatic diseases. Pfizer Medical Monographs No 3. Edinburgh: University Press, 1968: 96-103.

7 Naiman J L, Harcke T, Sebastianelli J, Stein B S. Scrotal imaging in the Henoch Schönlein syndrome. $J$ Pediatr 1978; 92: 1021-2.

Correspondence to Dr Noel $\mathbf{J}$ Tangney, Department of Paediatrics, Bon Secours Hospital, College Road, Cork, Ireland.

Received 21 January 1981 